\title{
The direction of oral health in the aging society
}

Dong-Hun Han

Managing Editor of the Journal of Korean Academy of Oral Health

Last winter, a volunteer mentoring program for rural branch middle school students in Chungcheongnam-do was hosted by university students.

A large memorial monument was erected in front of the town office. On April 4, 1919, it was a monument of praise of the independence movement that started in this town. At that time, nearly 2,000 villagers protested for independence, and nearly 150 people were killed or put in jail. Their names were inscribed on the monument to honor each of them.

I spent three hours roaming the village and came across a few people. According to principal of the branch school, about 40 villagers died last year, with only one birth—a typical aging village. A hundred years ago, a village of 2,000 villagers took to the streets, and now it is becoming a village where you could not hear a baby crying, a village where people could barely be found.

The near future that we will face will be quite different from the past, as shown by the government's announcement that 1,503 (43.4\%) out of 3,463 townships nationwide are in danger of extinction due to the low birth rate and aging population. Medical services will also need to change from provider-centered to patient-centered service delivery systems. The recently discussed dental healthcare service such as family dentists for children's and adolescents, family dentists for the disabled, and senior care facilities' dentists are an example of changing medical services.

Furthermore, it is time to discuss with how to provide dental services (as well as who will provide those services, and for how much) in areas where the population is dying.

March 2019 


\section{고령화 시대 구강보건의 방향}

한동헌

대한예방치과·구강보건학회 편집이사

지난 겨울, 대학생들과 함께 충청남도의 분교가 위치한 지역의 중학생을 대상으로 멘토링 프로그램을 진행했다. 멘토링 프로그램 중 간중간 마을을 둘러보는데 몇 가지 흥미로운 사실을 알 수 있었다.

면사무소 앞에 커다란 추모비가 세워져 있었다. 1919년 4월 4일 이 마을에서 시작한 독립만세운동을 기리는 비였는데 당시 2,000명 가까운 마을 사람들이 독립을 요구하는 시위를 벌였고, 150 명 가까운 사람들이 죽거나 감옥에 갇혔는데, 그 분들을 하나하나 기리기 위 해 세운 비라는 설명이 있었다.

약 세 시간 동안 마을을 돌아다녔는데 마주치는 사람이 거의 없었다. 분교장 선생님 말씀에 따르면, 작년 사망자가 40 여 명 이었는데, 출생자는 1 명이었다고 하는 전형적인 고령화 마을이었다. 100 년 전에 2,000 명의 마을 주민이 거리로 나왔던 마을이 이제는 아기 울음소 리를 들을 수 없는 마을, 사람을 찾아보기 어려운 마을이 되어가고 있었다.

저출산 고령화로 인해 대한민국의 전국 3,463개 읍면동 가운데 소멸 위험에 처한 지역 수가 2018년 1,503개(43.4\%)라는 정부 발표 로 알 수 있듯이 우리가 맞이할 가까운 미래는 지금까지 겪은 과거와는 상당히 다를 것이다. 의료서비스 역시 의료기관 중심의 서비스 제 공에서 환자 중심의 서비스 제공체계로 바뀌어야 할 것이다. 최근 이야기되는 아동청소년치과주치의, 장애인 주치의, 노인요양시설 치과 촉탁의는 변화하는 의료서비스 제공의 사례이다. 더 나아가 인구가 소멸하는 지역의 치과의료서비스를 누구에게 초점을 맞추어, 얼마나, 어떻게 제공할 지에 대한 논의가 필요한 시점이다.

2019.3. 